\title{
Anchorperson: An Emerging Phenomenon in the Electronic Media
}

\section{Muhammad Khalil Khan, International Islamic University Islamabad, Pakistan Farish Ullah Yousafzai, University of Gujrat, Pakistan,}

\begin{abstract}
This research study mainly focuses the imprudent role of the anchorpersons working in different news and current affair channels as an emerging phenomenon in electronic media. The study is designed to investigate the perceptions of audience members regarding the role of anchorpersons in different TV talk shows. In this study, it is hypothesized that the anchorpersons are biased toward certain political parties/groups and try to impose their own point of view on the panel and ultimately on the viewers; and they are not following the basic ethics of fairness and objective approach that is the fundamental duty of the information media. Descriptive survey research technique was used to find out what exists at the moment in the audience's perception about anchorpersons. Two hundred forty respondents were selected through proportionate stratified random sampling technique. Gender and level of education was used as strata for selection of appropriate sample for this study. The researcher used closed ended questionnaire to obtain the opinion of the audience regarding the role of anchorperson in TV talk shows. The empirical indicators of the study confirmed that anchorpersons were lacking professional experience and violate media ethics. The respondents believe that the anchorpersons often try to dictate the audience by imposing their own point of view. They are not only giving the analysis but also determine the direction. They violate professional ethics by slanting the facts and biased analysis. They often used derogatory words for the panel and ask personal question to prove them guilty. Overwhelming majority of the respondents believe that anchorpersons have become agent provocateurs.
\end{abstract}

Keywords: Anchorpersons, Talk shows, Electronic Media, Audience's Perception, Dictation, Slanting the Facts, Biased Analysis, Derogatory Words, Agent Provocateurs 


\section{Introduction}

The growth of news media in Pakistan in last few years has traumatized media landscape in the country. Specially, the fame gained by the private news channels in very short span of time is incredible. Private news channels have increased political awareness among audience through political talk shows. Thus the role of anchorpersons hosting these political talk shows has become very important. Cheema (2011) has noted that the level of awareness about the socio-political scenario has increased enormously due to political talk shows. The bombardment of information by the news channels and phenomenon of breaking news has enabled the audience to retrieve the desired information within no time. Today, the audience is better informed and has interactive participation in the socio-political affairs of the country. But this all would not be possible without the effective role of anchorpersons hosting different talk shows on the different TV channels. These talk shows have created socio-political awareness in the society and today society is in a better position to evaluate the critical role of government and opposition in the country. However, the negative aspect of this liberalization also invokes the hunger for power and personal projection in the media. Dhamrah (2012) noticed that media failed to deliver quality information to the audience with social and moral responsibility due to the race of popularity and intension to break news first which created chaos and false perception in the society on certain social issues. The aspect of dramatization and manipulation of facts and figures, angling the news story or inducing sensationalism in the story for the sake of attaining higher ranking among the audience has introduced unhealthy competition in the media. The irresponsible attitude of anchorpersons to impose their opinion and thoughts on the audience and trying to dictate their minds has evolved a new concept of anchorocracy in the Pakistani media.

\section{Anchorocracy}

Nizamani (2010) is of the view that media has shaped a new power sharing segment in society known as anchorocracy, where anchorpersons from different channels not only try to impose their opinion and thoughts but also indirectly indoctrinate the public with the ideology premeditated by the anchorocracy. Sareen (2010) a senior fellow in Vivekananda International Foundation (VIF) refers the term anchorocracy for TV anchorpersons. She believes that most of them are from rightwing having Islamic tendencies. They have taken upon themselves to set the national agenda and articulate and promulgate on everything without knowing much of anything. 
Experts believed that the term anchorocracy have negative connotation due to the bureaucratic attitude of the anchorpersons belonging to different private news channels whose ultimate desire is to impose their opinion and thought on audience. They want to dictate the audience mind on sensitive issues with a firm belief that they are promoting national interest and audience should follow their lines.

\section{Anchorocracy and its Impact on Society}

The expansion of news media in Pakistan in the last few years has shattered the power pillars of the state and has curtailed the previously held unlimited powers of bureaucracy. It creates a new parallel power sharing segment known as anchorocracy. This shift of power from bureaucracy to anchorocracy has put a bridle in the nose of new born democratic government in Pakistan. Anchorpersons in Pakistani private news media seemingly started crossing their ethical and moral limitations. They seem to indulge themselves into arguments on different critical socio-political issues. They are presumably trying to inculcate the public with their own ideology. They not simply present the facts but also impose their own perspectives. They usually make prediction about the future of democratic government, about judiciary decision on controversial issues and even on the role of military establishment. They sometimes behave like reformist and representative of the general public which lead them to become a party in discussion process. The role of mediator is going behind the scene. Now they seem to consider that it is their right to advocate their stance on crucial issues. Uks (2010, p.41) stated in its report that lower income segment and youth of Pakistan think that anchorperson wants to dictate audience minds. They believe that anchorperson instead of resolving the issues, make them more complicated.

Today, there is a big question mark on the authenticity and impartiality of the TV anchorpersons. There is a continuous race among the anchorperson to break the story first which undermine the strong editorial judgment of news selection. Anchorpersons often disseminate immature, incorrect and exaggerated information in lieu to get higher ranking among the competitors. Lack of prescribe rules and absence of fixed standard in Pakistan, allowing individuality within a prescribed framework. Due to lack of professionalism and broadcasting ethics, some of the TV anchorpersons are not even fit for the job. 


\section{Anchorpersons as Columnists}

Most of the anchorpersons are also contributing columns to Urdu or English Newspapers. Normally columns are based on highly personalized opinion of the author about an issue. Columns are less objective and mostly based on belief and opinion of the columnists. Shahid (2009) has a view that column is an individual opinion and expression about a wide range of issues ranging from politics to hobbies. It presents the opinion of the author, whose by-line appears at the top of each column. He further argues that columnist may pass comments on the important issues or he may favour any side. Yousafzai (2003) argues that the columnists mostly violate the basic precepts of journalistic writing. They pass judgments and make recommendations which cannot be accepted in any other piece of writing.

However, it is very important to understand the difference between writing a column in newspaper and anchoring a TV talk show in the News channels. Najam Satti (2010), a senior journalist believes that Job of an anchorperson is to take the opinion rather to give opinion to people. But today anchorpersons are trying to put words in the mouth of leading personalities and trying to impose their own perspective. Some of the anchorpersons have political affiliations or sympathies for a particular political party or political leader. On the basis of this association, they support or oppose that particular political party or leader in a persistent way and often in blatant manner which is against the professional ethics. Even some time, anchorpersons directly accused the participant without having any concrete evidence against him e.g. a well known TV anchorperson during his political talk show "Point Black" on news channel on Dec. 26, 2010 directly accused Safdar Abbasi, a PPP dissident senator for the Banazir Butto’s assassination without any concrete evidence.

\section{Political Maneuvering}

Vigna and Ethan (2007) noticed that media play an important role in shaping the political preferences and belief of voters. He argues that media collects information, summarizes it and frames it according to its own preferences which influenced the voting decisions of voters. DeMarzo, Vayanos, and Zwiebel (2003) also argue that media persuades voters because they are unaware of bias in the media.

Critics argues that Pakistani media has its own likes and dislikes particularly most of the anchorpersons often focus on one side of the issue and eventually polarize the situation. A 
famous TV anchorperson has conducted clearly political motivated program "Capital Talk" on Geo News on 23 Feb 2010, a day before poll in NA-55 (Rawalpindi) in which he brought forward some controversial statement of Sheikh Rasheed Ahmad against PPP leadership in the past and the issue of Lal Masjid. Most of the analysts believe that before airing this program, the race between the two contestant i.e. Sheikh Rahseed Ahmad (AML) and Malik Shakeel Awan, PML (N) was too close but a day before the election, this program almost changed the whole scenario in favour of PML $(\mathrm{N})$ candidate who won the election on the very next day with a huge margin. This program changed the public perception about Sheikh Raheed Ahmad and specially provoked PPP workers not to support Sheikh Raheed Ahmad because he had used some indecent words against their party leadership in the past. Even on the same day, Governor Punjab, Suleman Taseer (PPP) had announced his full support for Sheikh Raheed Ahmad.

\section{Imprudent Role of Anchorperson and Government}

Anchorpersons have become so powerful that they directly threatening the stability of government. They often propagate raw information with out any evidence which creates an ambiguous situation. In October 2010, some anchorpersons claimed that government was planning to withdraw its notification regarding reinstatement of judges removed by General Musharaf. This unconfirmed and premature information has pushed the high judiciary to rush to Supreme Court and warned the government to refrain from taking such action. Later Supreme Court declared such action as treason under article 6 of the constitution. This news nearly caused a clash between the newly born democratic government and Supreme Court of Pakistan. If the Prime Minister was not quick enough to mitigate the situation, it was obvious that this crisis would have changed into a great disaster for the democratic government of Pakistan. 


\section{Anchorperson and Rating Phenomena}

According to the Oxford Advanced Learner's Dictionary, "rating" means "the popularity of a television or radio programme as measured by the number of people viewing or listening." The term "rating" is generally used for evaluating and assessing the quality of TV programs in terms of its viewership. The privatization of media in Pakistan, particularly after 2002, the commercial element in media has been increased to great extent. The role of media has now been changed. Today, the most important element in media is the financial interest of the owner. Advertising is the main source of income for the TV channels and advertisers always give advertisement to the channels having a huge viewership among the competitors. Therefore, to attract the attention of viewers, TV channel mostly hired the big name (Anchorpersons) of the media. These anchorpersons tried to dramatize the facts to attain the attention of viewer. Immature and imprudent news stories are telecast without any strong editorial check to get better rating among the rivals. The concept of rating is not justified because the literacy rate in Pakistan is very low. The viewers haven't critical and analytical sense to evaluate and assess the quality of content telecast in TV talk shows. The illiterate viewers like those who bitterly criticized the corrupt government in the country.

\section{Anchorperson: A Controversial Entity}

A well known TV anchorperson Mubashir Lucman (2010) tells in an interview to "The Daily Jinnah" that the anchorpersons of Pakistan are camels without bridle (Shutr-e-bemahar)." However the same anchorperson was blamed for a planted interview with Malak Riaz against judiciary in the case of Arsalan Iftikhar (son of Muhammad Iftikhar Choudhray, Chief Justice of Pakistan Suprem Court). A famous TV anchorperson and columnist, Saleem Safi (2010) has asserted in his column in the daily "Jang" that TV anchorpersons have become aql-e-kul (knowing-all) and start striking the pose of a mufti. Instead of taking and giving news they start creating news. Instead of analyzing the news they start giving dictation.

Some of the communication experts believe that anchorpersons have their own agenda and some time they even follow the agenda of their owner who always look into their financial benefits. They believe anchorpersons come up with preplanned agenda to align the public opinion with their own opinion about different cultural, religious and critical socio-political issues. Some of the anchorpersons openly declare that they have personal opinion about an 
issue to disseminate in the public. They believe people like or dislike them due to their diverse opinion on different crucial social and political issues (Shahid, 2010).

Ahmed (2010) believes that the anchorpersons have been given intensified coverage in news media and some of the TV anchorpersons have also articulated their opinion in print media. This dual coverage makes these anchorpersons more powerful that they dame care to rebound the guest opinion and often put forward their own opinion and thoughts. They even present something that is accusatory without any solid proof. He argues that anchorpersons become agent provocateur. They put the rival discussants together and expect them to quarrel each other. They often hype up the situation rather trying to calm down the situation between the rival discussants. They provoke the participants and make them to fight each other on different critical issues. Sometimes they ignite the situation so that the rival participants try to threat each other and make the discussion into a verbal wrestling. TV anchorperson Kamran Shahid (2011) admits that sometimes it becomes difficult to stop these rival participants when they start verbal fight.

Rizvi (2010) asserts that mostly anchorpersons in their talk shows trying to create controversies on the issues of public interest which they perceive the way to get better rating for his/her program. He suggests that information should be disseminated only when it passes through strong professional editorial judgment and its societal impact must be ensured. Gillani (2010) quotes Dr. Mehdi Hasan, Chairman, Human Rights Commission of Pakistan, by saying "Anchorpersons have every right to criticize the government, but many time they do it without proper research or evidence and without realizing how their 'declarations' will be received by the general public."

\section{Anchorpersons and Code of Ethics}

Today, no society can improve and develop its social structure without powerful, free and fair media. Freedom of press promotes openness and democratic traditions in societies. However, this freedom cannot be used as a license to create anarchy in the society by violating social and cultural norms or by using abusive and derogatory languages by the journalists (anchorpersons). Therefore, for the smooth functioning of media and to avoid any disruption in society, every country has prescribed some guide lines for the media to operate in efficient and responsible way for the betterment of the society. These guide lines are called ethics of 
journalism. The purpose of these codes of conduct is to ensure the free, fair and balance flow of information to the public and promote the peace, tolerance and democratic norms in the society through responsible journalism. Most common ethics for media are: accuracy, fairness, limitation of harm, acceptability, invasion of privacy, confidentiality, social responsibility, and stereo typing.

Scott (2002) underpins his views that "the comment is free, but facts are sacred." This statement of Scott provides guide line for the journalists that they are free to comment on the issues but do not try to manipulate the facts because facts are scared. Today, the commercial media has crippled the moral ethics of the media. Journalists are not only considering it is their right to comment on facts but also manipulating the facts to influence the public opinion. Anchorpersons working in different Pakistani media outlets are using freedom of media as a license to violets the social and ethical norms of the society. Justice Markandey Katju, Chairman of the Press Council of India criticized the irresponsible behaviour of Indian media while covering exodus of people from the northeast. He noticed that Indian media has aired the controversial SMSs without assessing the truth and spread fear. He believed that "The way the issue was handled; it sent a wrong message and forced people to run for their lives" (Time of India, 2012).

Cheema (2011) noted that new privately owned channels are highly opinion based. These channels are lacking original contents and greatly depend on opinion based reporting. Most of the analysis presented by the different anchorpersons is just like blame game where no sensible solution of the issue has been discussed. However, a few of the talk shows can be considered as informative and result oriented. One man analysis on the crucial and sensitive issue has also curtailed the balance flow of information in society. This new trend in talk shows has overthrown the element of discussion and plurality of opinion and changes the talk show into one man intellectuality which is highly personalized and egotistical.

Media critics acknowledge the media role as watchdog on state institutions to divulge transgression in state institutions and uncover the social injustice in the society. But argue for strong and efficient ombudsmen system for media to perform responsible role for the betterment of the society. They urge for an efficient role of press council and propose self regulation for media and journalists. They advocate the consumer rights and demand for 
strong self censorship for effective role of media in society. Different government and journalistic bodies have also prescribed different codes of ethics for the media practitioners in Pakistan. Pakistan Federal Union of Journalists (PFUJ) issued code of conduct for the journalists in 1949. In 1954, reporters and senior editors proposed a 13 points code of conduct. Idea of press council was introduced by Ayub Khan including owners, editors, working journalists, university professors, and civil servant headed by high court judge. However, this idea was refused by the media owners. PEMRA ordinance was promulgated in 2002 by General Pervaiz Musharaf which provided guide line for media to operate in the country. Role of Press council was reconstituted through press council ordinance 2002. However, media owners and journalist are not following these codes of ethics. In 2008, when Pakistani media violated the social norms and traditional journalism, International federation of Journalists (IFJ) proposed some suggestions for Pakistani media. These suggestions were based on constitution of free press council, self-regulation for media, element of accountability and strong ethical based professional journalism. PFUJ also supported these suggestions.

\section{Statement of Problem}

The role of the TV anchorperson is very important in opinion making of the audience members. The literacy rate is low in the developing societies like Pakistan. People usually believe in the media wherever awareness level is not so high. There is a serious debate among the politicians and even the media persons themselves: i. whether or not the anchorpersons are biased and partisan towards some social, political, religious and economic issues; ii. what should be their legitimate role as media persons during conducting talk shows on different issues? However, very few studies have been conducted to inquire audience's perception towards the role of the anchorpersons. So the need is immense to scientifically inquire the audience's perception regarding this new phenomenon.

The following questions are posed to investigate how viewers perceive the role of anchorpersons in TV talk shows:

1. Do viewers perceive that anchorpersons are playing partial role in TV talk shows?

2. Do viewers perceive that anchorpersons are slanting information?

3. Do viewers perceive that anchorpersons of different news channels have sympathies with different political parties? 
4. Do viewers perceive that anchorpersons are imposing their own perspectives?

5. How viewers perceive about the attitude of anchorpersons towards their guests in TV talk shows?

6. Do viewers consider anchorpersons as agent provocateurs?

\section{Rationale}

The anchorperson is an important entity in news media. The role and importance of anchorpersons has remained the centre of talks in the west. However, this phenomenon is new in Pakistan. Therefore, it is the right time to understand, evaluate and analyze the role of anchorperson, which is holding the most important place in news media. The role of an anchorperson is like a life line between the information and audience. He/she is like gatekeeper who control the in and out flow of information. Cartwright (1949, p.155) has noted, "It is conceivable that one persuasive person, through the use of mass media, could bend the world population to his own will."

\section{Method}

Descriptive survey technique was used to investigate the perception of the viewers about the role of TV anchorpersons in the Pakistani news channels' talk shows. Stratified random sampling technique was adopted to select the appropriate sample for this study. This sampling approach is used to select the adequate desired subsample (strata or segment) of population which contain any variable (age, sex, educational level and socio economic status etc). It ensures that sample is drawn from a homogenous population having similar characteristics.

The researcher randomly selected 240 respondents from both male and female students of Journalism/Mass Communication departments of two public sector universities viz. International Islamic University, Islamabad and National University of Modern Languages (NUML), Islamabad by using the stratification equally divided on the basis of gender and educational level to get their opinion on the phenomenon under investigation. The respondents were divided into two categories viz. male (120 respondents) and female (120 respondents). Male and female categories were further divided on educational stratum viz. BS and M.Sc. The researcher selected 60 respondents (30 male and 30 female) of BS and 60 respondents (30 male and 30 female) of M.Sc classes from International Islamic University, Islamabad. The similar fraction of male and female students of BS and M.Sc were selected 
from National University of Modern Languages (NUML), Islamabad. The responses of the students were collected on five degree scale (likert scale i.e. strong agree, agree, uncertain, disagree and strongly disagree) through closed ended questionnaires and analyzed on SPSS Version 16.0.

\section{Results}

Finding-1. Majority of the respondents $(79.7 \%$ ) believe that anchorpersons are not only giving analysis but also determine the direction of important issues whereas $11.9 \%$ of the respondents are not sure whether anchorpersons are determining direction for important issues along with giving analysis on that important issue. However, $8.5 \%$ of the respondents said that anchorpersons are impartial while conducting their programs.

Table 1: Biasness of anchorperson

\begin{tabular}{|l|c|c|c|}
\hline Level of agreement & Frequency & Percent & Cumulative Percent \\
\hline Strongly Agree & 37 & 15.7 & 15.7 \\
\hline Agree & 151 & 64.0 & 79.7 \\
\hline Uncertain & 28 & 11.9 & 91.5 \\
\hline Disagree & 12 & 5.1 & 96.6 \\
\hline Strongly Disagree & 8 & 3.4 & 100.0 \\
\hline Total & 236 & 100.0 & \\
\hline
\end{tabular}

Finding-2. Majority of the respondents (71.6\%) agree that anchorpersons of Pakistani TV news channels are slanting information. However, $21.6 \%$ of the respondents were not sure whereas, $6.8 \%$ of the respondents have showed disagreement with notion that anchorpersons of Pakistani news and current affair channels are slanting information.

Table 2: Biasness of Anchorperson by slanting information

\begin{tabular}{|c|c|c|c|}
\hline Level of agreement & Frequency & Percent & Cumulative Percent \\
\hline Strongly Agree & 26 & 11.0 & 11.0 \\
\hline Agree & 143 & 60.6 & 71.6 \\
\hline Uncertain & 51 & 21.6 & 93.2 \\
\hline
\end{tabular}




\begin{tabular}{|l|c|c|c|}
\hline Disagree & 15 & 6.4 & 99.6 \\
\hline Strongly Disagree & 1 & .4 & 100.0 \\
\hline Total & 236 & 100.0 & \\
\hline
\end{tabular}

Finding-3. Majority of the respondents (54.7\%) agree that anchorpersons of Pakistani TV news and current affairs channels have sympathies with different political parties. However, $25.9 \%$ of the respondents believe that anchorpersons of Pakistan news and current affair channels have not any sympathies with different political parties whereas, $19.5 \%$ of the respondents are uncertain about the phenomenon.

Table 3: Political biasness of Anchorpersons

\begin{tabular}{|l|c|c|c|}
\hline Level of agreement & Frequency & Percent & Cumulative Percent \\
\hline Strongly Agree & 46 & 19.5 & 19.5 \\
\hline Agree & 83 & 35.2 & 54.7 \\
\hline Uncertain & 46 & 19.5 & 74.2 \\
\hline Disagree & 46 & 19.5 & 93.6 \\
\hline Strongly Disagree & 15 & 6.4 & 100.0 \\
\hline Total & 236 & 100.0 & \\
\hline
\end{tabular}

Finding-4. Majority of the respondents $(63.1 \%)$ have a view that anchorpersons are trying to dictate the participants and put words in their mouth. However, $21.5 \%$ of the respondents do not sure whether anchorpersons are trying to dictate the participants whereas, $15.3 \%$ of the respondents are not agreeing with the idea.

Table 4: Anchorperson as dictator

\begin{tabular}{|l|c|c|c|}
\hline Level of agreement & Frequency & Percent & Cumulative Percent \\
\hline Strongly Agree & 38 & 16.1 & 16.1 \\
\hline Agree & 111 & 47.0 & 63.1 \\
\hline Uncertain & 51 & 21.6 & 84.7 \\
\hline Disagree & 33 & 14.0 & 98.7 \\
\hline
\end{tabular}




\begin{tabular}{|l|c|c|c|}
\hline Strongly Disagree & 3 & 1.3 & 100.0 \\
\hline Total & 236 & 100.0 & \\
\hline
\end{tabular}

Finding-5. Majority of the respondents $(70.8 \%)$ have a view that anchorpersons working in different news channels are trying to snub the guest's arguments on the important issues whereas only $9.8 \%$ of the respondents are disagreeing with the statement. However, $19.5 \%$ of the respondents are not clear whether anchorpersons tried to snub the guest's arguments on the important issues or not.

Table 5: Anchorperson snubs guest's arguments

\begin{tabular}{|l|c|c|c|}
\hline Level of agreement & Frequency & Percent & Cumulative Percent \\
\hline Strongly Agree & 20 & 8.5 & 8.5 \\
\hline Agree & 147 & 62.3 & 70.8 \\
\hline Uncertain & 46 & 19.5 & 90.3 \\
\hline Disagree & 19 & 8.1 & 98.3 \\
\hline Strongly Disagree & 4 & 1.7 & 100.0 \\
\hline Total & 236 & 100.0 & \\
\hline
\end{tabular}

Finding-6. Majority of the respondents $(51.7 \%)$ believe that anchorpersons working in different news channels often uses derogatory words in their talks and insulted the guests whereas, $24.2 \%$ of the respondents believes that anchorpersons are not using derogatory word in their talks and do not insult the guests. However, $24.2 \%$ of the respondents are uncertain about the phenomenon.

Table 6: Use of derogatory language by Anchorperson

\begin{tabular}{|l|c|c|c|}
\hline Level of agreement & Frequency & Percent & Cumulative Percent \\
\hline Strongly Agree & 28 & 11.9 & 11.9 \\
\hline Agree & 94 & 39.8 & 51.7 \\
\hline Uncertain & 57 & 24.2 & 75.8 \\
\hline Disagree & 49 & 20.8 & 96.6 \\
\hline
\end{tabular}




\begin{tabular}{|l|c|c|c|}
\hline Strongly Disagree & 8 & 3.4 & 100.0 \\
\hline Total & 236 & 100.0 & \\
\hline
\end{tabular}

Fiding-7. Majority of the respondents (49.2\%) agree that anchorpersons ask personal questions from the guest to prove him guilty whereas, $27.5 \%$ of the respondents believe that anchorpersons do not ask personal questions from the participants to prove them guilty. However, $23.3 \%$ of the respondents are not cleared whether anchorpersons asked personal questions from the guests to prove them guilty or not.

Table 7: Use of personal questions to insult guest

\begin{tabular}{|l|c|c|c|}
\hline Level of agreement & Frequency & Percent & Cumulative Percent \\
\hline Strongly Agree & 35 & 14.8 & 14.8 \\
\hline Agree & 81 & 34.3 & 49.2 \\
\hline Uncertain & 55 & 23.3 & 72.5 \\
\hline Disagree & 55 & 23.3 & 95.8 \\
\hline Strongly Disagree & 10 & 4.2 & 100.0 \\
\hline Total & 236 & 100.0 & \\
\hline
\end{tabular}

Finding- 8 . Majority of the respondents $(44.5 \%)$ believe that anchorpersons are not following any code of ethics in their TV talk shows whereas, $33.5 \%$ of the respondents are not agree with the statement that anchorpersons are not following any code of ethics. However, $22 \%$ of the respondents are uncertain about the phenomenon.

Table 8: Violation of code of ethics

\begin{tabular}{|l|c|c|c|}
\hline Level of agreement & Frequency & Percent & Cumulative Percent \\
\hline Strongly Agree & 31 & 13.1 & 13.1 \\
\hline Agree & 74 & 31.4 & 44.5 \\
\hline Uncertain & 52 & 22.0 & 66.5 \\
\hline Disagree & 70 & 29.7 & 96.2 \\
\hline Strongly Disagree & 9 & 3.8 & 100.0 \\
\hline
\end{tabular}




\begin{tabular}{|l|c|c|c|}
\hline Level of agreement & Frequency & Percent & Cumulative Percent \\
\hline Strongly Agree & 31 & 13.1 & 13.1 \\
\hline Agree & 74 & 31.4 & 44.5 \\
\hline Uncertain & 52 & 22.0 & 66.5 \\
\hline Disagree & 70 & 29.7 & 96.2 \\
\hline Strongly Disagree & 9 & 3.8 & 100.0 \\
\hline Total & 236 & 100.0 & \\
\hline
\end{tabular}

\section{Discussion and Conclusion}

The results of the study reveal that majority of the respondents (69.1\%) agree that anchorpersons of Pakistani TV news channels are imparting their own views in their TV talk shows instead of giving impartial analysis of the important issues whereas, awesome majority of the respondents $(71.6 \%)$ believe that anchorpersons of Pakistani TV news channels are slanting information. The results of the study also illustrate that $54.7 \%$ of the respondents have opinion that anchorpersons of Pakistani TV news channels have sympathies with different political parties and they are politically motivated. The role of anchorperson as dictator is noticeably perceived by the viewers. A handsome majority of the respondents (63.1\%) have a view that anchorpersons are trying to dictate the participants and put words in their mouths. Moreover, $79.7 \%$ of the respondents believe that anchorpersons are not only giving analysis on the important issues but also determine the direction on these important public issues.

The finding of the study elucidates that anchorpersons working in different Pakistani TV news channels are violating the code of ethics in their talk shows. Forty five percent of the respondents believed that anchorpersons working in different news and current affairs television channels are not following any code of ethics in their TV talk shows. More than half of the population sample $(51.7 \%)$ of the respondents believes that anchorpersons working in different news and current affair channels often use derogatory language in their talks. Majority of the respondents (49.2\%) were agreed that anchorpersons asked personal questions from the guests to prove them guilty. A great number of respondents $(70.8 \%)$ has pointed out that anchorpersons working in different channels are trying to snub the guest's arguments on the important issues. 
The role of anchorperson as agent provocateur was also studied in this research studies. The results indicates that overwhelming majority of the respondents (75.8\%) agree that anchorpersons working in different news and current affairs television channels provoke rival discussant to start heated conversation for getting higher rating for their programmes. 


\section{References}

Cartwright, D. (1949). Cited in J. Bryant and D. Zilmann (Eds.), Media Effects: Advances in Theory and Research, Hove: Lawrence, 1994.

Cheema, Adnan Bashi (2011) Exploring the impact of talk shows on private TV channels: A case study of Geo and Express TV Channels, MS level thesis, presented in Allma Iqbal Open University, Islamabad

Dhamrah. H. Mohammed (2012). Violation of Media Ethics. Roshni.com. Retrieved from http://weeklyroshni.com/articles/english/Hosh\%20Mohammad\%2012.htm

DeMarzo. P, Vayanos. D. \&Zwiebel. J. (2003). "Persuasion Bias, Social Influence, and UniDimensional Opinions", Quarterly Journal of Economics, 118, 909-968, 2003.

Gillani, Waqar (2010, October 3). The role of the gatekeeper, The New, Opinion page

Kamran Shahid (2010, November 19), News night with Talat, Dawn News TV.

Mubashir Lucman (2011, January 13), Point Blank, Express News TV.

Mubashir Lucman (2010, 14 January). Interview with Lucman, Daily Jinnah, Islamabad.

Najim Satti (2010, July 12), Views on News. ARY News TV.

Nizamani, N (2010). VIEW: Heading towards revolt or disaster, Baloch Society of North America (BSO-NA).

PEMRA (2011) Retrieved on Jun 14, 2011 from http://www.pemra.gov.pk

PFUJ (2011) Retrieved on Nov 11, 2011 from http://pfuj.pk

“Rating” Oxford Advanced Learner's Dictionary. $5^{\text {th. }}$ ed. Oxford: Oxford University Press, 1995. Print

Rizvi, Hasan Askari (2010), Democracy and media, SAFMA National Conference-VI, Media, Democracy and Good Governance, Islamabad. P. 13-4.

Shahid. M. Imtiaz (2009).Editorial Page. Mass Communication: Introducing New Trends. Advanced Publisher, Lahore.

Saleem Safi (2010, March 30). Qanun or Qaundan (Law and Lawyer), Jerga, Jang, Opinion Page.

Sareen. S. (2010), Floods: Pakistan Bracing for the Fallout, Vivekananda International Foundation

Scott. C.P (2002, November 29), Comment is free, but facts are sacred. The Guardian, London. Retrieved on 11 Nov. 2001 from Www.guardian.co.uk/commentisfree/2002/nov/29/1

Shahid Masood (2010, July 12., Views on News. ARY News TV. 
The Times of India (2012, August 27). Electronic media sent wrong message on exodus: Katju.

Uks (2010), "Pakistan ma Talk Show ka tajzia” Awam sa Guftagu, Uks- a research, resource \& publication centre of women and media, Islamabad.

Vigna. S. D. \& Ethan K. (2007). The Political Impact of Media Bias, Retrieved from http://elsa.berkeley.edu/ sdellavi/wp/mediabiaswb07-06-25.pdf

Wimmer. R. D. \& Dominick. J. R. (1994). Survey Research. Mass Media Research: An Introduction ( $4^{\text {th }}$ ed.) California. Wadsworth Publishing Co.

Yousafzai, F.U (2003), Column writing, Print Media, Allama Iqbal Open University, Islamabad. 